\title{
Skeletal Maturation in the pediatric population in a large tertiary care hospital in South India
}

\author{
Vijayalaksmi G. ${ }^{1}$, Rajiah J. ${ }^{2}$ \\ ${ }^{1}$ Dr Vijayalaksmi G, Professor of Radiology, Institute of Child Health \& Hospital for Children, Chennai, ${ }^{2}$ Dr Jeya Rajiah, \\ Associate Professor, Tirunelveli Medical College, Tirunelveli, Tamilnadu, India.
}

Address for Correspondence: Dr Vijayalaksmi G, Professor of Radiology, Institute of Child Health \& Hospital for Children, Chennai, Address: 51, Officers Lane, Cantonment Pallavaram, Chennai. Email: drviji.rad@gmail.com

\begin{abstract}
Background \& Objectives: Determination of skeletal age is an important part of examination for many clinical problems with growth disorders. The Greulich and Pyle atlas method and the Tanner Whitehouse technique are used to assess bone age accurately. However time constraints force pediatricians to quickly assess bone age from age of appearance of epiphyseal centres. The aim of this study was to re-examine this method in today's clinical practice to enable more practical and appropriate use. Methods: The study was undertaken in The Institute of Child Health and Hospital for Children, Egmore, (ICH \& HC) Chennai. Normal children less than 12 years were included in the study. The children were grouped in different age groups, 100 girls and 100 boys in each age group totalling 3800 children. Depending on the chronological age of the child only the $\mathrm{x}$ ray films of the hand, wrist, elbow, or knees were taken. We used x-rays of hands for all age groups and elbow in those over 5 years. Only the appearance of ossification centers was noted. We also used x-ray of the patella for children in 3 to 5 year age groups. Results: We found that the mean age of appearance of patellar ossification was similar in both boys and girls (mean age 4.8 \pm 0.5). By 3-6 months capitate and hamate were present in all children (mean age $0.5 \pm 0.1$ ). There is high variability in the timing of ossification of carpal bones, which accounts for their elimination for age evaluation. However the pisiform follows a constant mean age at 10.6 for girls and 11.6 for boys. Conclusion: Children can be adequately screened for age assessment from $\mathrm{x}$ rays of the hands in the early stages (upto 2 and half years) and later the elbows. We propose the use of knees lateral for patellar centre for children more than 3 and less than 6.
\end{abstract}

Key words: Skeletal Maturation, skeletal age, Pediatric population

\section{Introduction}

Determination of skeletal maturity is a part of medical examination for many clinical problems. The oldest method noted the age of appearance of epiphyseal centres in X-rays. Later, the Greulich and Pyle [1] atlas method and the Tanner and Whitehouse [2] scoring technique were based on the changes in the forms of ossification centres in the course of growth. These two methods have improved accuracy and revolutionised skeletal age assessment [3].

However many clinicians, paediatricians and radiologists still assess age based on the first method.

Manuscript received $20^{\text {th }}$ September 2016

Reviewed: $4^{\text {th }}$ October 2016

Author Corrected: $16^{\text {th }}$ October 2016

Accepted for Publication $31^{\text {st }}$ October 2016
Reasons proffered are a lack of time to pore over atlases and requirement for a quick reckoner that will help in preliminary sorting of cases regarding skeletal maturation status. Another reason for continued use of our method is because skeletal maturity varies as much as two years on either side of the chronological age of normal healthy children between 5 and 14 years [2]. For initial diagnoses a discrepancy with the chronological age of 2 to $3 y$ is the order of detection required [4]. If this is the case we have found that our method could be very useful.

This study reexamines the method, dispels certain myths $[5,6]$ and offers modification to enable more sensible use. 


\section{Methods}

Place of study- The study was undertaken in The Institute of Child Health and Hospital for Children, Egmore (ICH \& HC) Chennai which holds the distinction of being the largest hospital for children in Asia. Study period- The study period extended from 2006 to 2013. Sampling- Consecutive sampling Children taken into the study were those attending OP for simple ailments.

Inclusion Criteria- Children less than 12 years (y) of age. Acute respiratory illnesses less than a week were also included. Only those children with weights and height falling within normal, according to the NCHS growth charts [7] (between 3rd and $97^{\text {th }}$ percentile curves), were taken into the study.

Exclusion crite ria- Adolescents were excluded. ICH \& $\mathrm{HC}$ does not cater to children more than twelve years of age. Consequently only the appearance of ossification centers and not the fusion is noted. Children with history of serious illness like fever of more than four weeks, acute or chronic renal failure, glomerulonephritis or treatment for leukaemias, those with gross physical and mental defects were excluded.

Statistical analysis- Descriptive statistical analysis was done. Mean, Range, Standard Deviation and percentile values for 5th, 50th and 95th percentiles were derived 92\% of children were Tamil and the rest were from South Andhra (7\%), Odisha and Kerala (1\%).

After ascertaining that the children satisfied the inclusion criteria, specific x-rays were taken.

Based on observations over many years and recorded standards of appearance of specific ossification centers certain $\mathrm{x}$ rays were taken so that maximum useful information is obtained with minimum of exposures.

Depending on the chronological age of the child only $\mathrm{x}$ ray films of the hand, wrist, elbow, or knees were taken.
1. Both hands with wrists AP - all children.

2. Three years and more- both knees lateral is also taken. The knees may be excluded in children over $6 y$ if maturation in the elbow is proceeding normally eg: if ossification centre for radial head has appeared.

3. Five years and more- both elbow $\mathrm{x}$ rays is added to the hands.

Both sides were $\mathrm{x}$ rayed but there is no difference between the sides as was evident in our study. This is in agreement with other authors [1]. Any one side may be taken. The age groups are from the new born up to 12 years. Actual ages were noted since correct date of birth is known. While some may be evaluated in the beginning of the chronological year others may be examined in the latter half of the year. On a practical level, appearance and size of the previously appearing centres will help an observer in coming to a conclusion whether growth is proceeding normally. In our study only the appearance of centres were noted.

This is an easy observation which could be made by any new or unfamiliar observer. It is an objective decision.

There is no matching from atlases. The children were divided and grouped into three month intervals up to one year, then six monthly intervals up to 5 years and then annually up to 12 years. The number of groups therefore is 19.100 children in each group were studied.

Boys and girls were recorded separately. 100 boys and 100 girls in each age group totalled to 3800 .

The varying intervals of time are due to the fact that the skeletal development of the hand does not progress rapidly enough after age of five, to warrant more frequency than annual intervals [2]. This might not be true around puberty [8]. The appearance of the ossification centres were noted and entered into tabular columns for computation.

\section{Results}

The third and fourth proximal phalanges appear by 1 year 9 months. All the centres of the $3^{\text {rd }}$ and 4 th phalanges were present by 2 years \& 3 months. The 5th middle phalanx appears at the same time but the proximal and distal phalanges are delayed up to 3 years 9 months.

The carpal bones show a wide variation in their age of appearance, however the pisiform is quite constant and shows a mean age of appearance of 10 years and 6 months in girls and 11 years 6 months in boys. 
Table-1: Descriptive statistics for various parameters for boys.

\begin{tabular}{|c|c|c|c|c|c|}
\hline \multicolumn{6}{|c|}{ PERCENTILE } \\
\hline PARAMETER & MEAN土SD & $5^{\text {th }}$ & $50^{\text {th }}$ & $95^{\text {th }}$ & RANGE \\
\hline $\mathrm{C} 1$ & $0.50 \pm 0.18$ & $3 \mathrm{~m}$ & $6 \mathrm{~m}$ & $6 \mathrm{~m}$ & $3 m-6 m$ \\
\hline $\mathrm{C} 2$ & $0.98 \pm 1.24$ & $3 \mathrm{~m}$ & $6 \mathrm{~m}$ & $6 \mathrm{~m}$ & $3 m-6 m$ \\
\hline $\mathrm{C} 3$ & $4.23 \pm 1.43$ & $2 \mathrm{y} 9 \mathrm{~m}$ & $4 y 3 \mathrm{~m}$ & $7 y 6 m$ & $2 y 9 m-7 y 6 m$ \\
\hline $\mathrm{C} 4$ & $5.97 \pm 1.39$ & $4 y 3 \mathrm{~m}$ & $5 y 6 m$ & $9 y 6 m$ & $4 y 3 m-9 y 6 m$ \\
\hline C5 & $7.48 \pm 1.10$ & $6 y 6 \mathrm{~m}$ & $7 y 6 m$ & $9 y 6 m$ & $6 y 6 m-9 y 6 m$ \\
\hline C6 & $7.87 \pm 1.00$ & $6 y 6 \mathrm{~m}$ & $7 y 6 m$ & $9 y 6 m$ & $6 y 6 m-9 y 6 m$ \\
\hline $\mathrm{C} 7$ & $8.47 \pm 0.95$ & $6 y 6 \mathrm{~m}$ & $8 y 6 m$ & $9 y 6 m$ & $6 y 6 m-9 y 6 m$ \\
\hline DR & $1.53 \pm 0.30$ & $1 \mathrm{y} 3 \mathrm{~m}$ & $1 \mathrm{y} 9 \mathrm{~m}$ & $1 \mathrm{y} 9 \mathrm{~m}$ & $1 \mathrm{y} 3 \mathrm{~m}-1 \mathrm{y} 9 \mathrm{~m}$ \\
\hline $\mathrm{MC1}$ & $3.03 \pm 0.51$ & $2 \mathrm{y} 9 \mathrm{~m}$ & $3 \mathrm{y} 0 \mathrm{~m}$ & $4 \mathrm{y} 0 \mathrm{~m}$ & $2 \mathrm{y} 9 \mathrm{~m}-4 \mathrm{y} 0 \mathrm{~m}$ \\
\hline $\mathrm{MC} 2$ & $1.92 \pm 0.36$ & $1 \mathrm{y} 3 \mathrm{~m}$ & $1 \mathrm{y} 9 \mathrm{~m}$ & $2 \mathrm{y} 3 \mathrm{~m}$ & $1 y 3 m-2 y 3 m$ \\
\hline MC3 & $1.97 \pm 0.35$ & $1 \mathrm{y} 3 \mathrm{~m}$ & $2 \mathrm{y} 3 \mathrm{~m}$ & $2 \mathrm{y} 3 \mathrm{~m}$ & $1 \mathrm{y} 3 \mathrm{~m}-2 \mathrm{y} 3 \mathrm{~m}$ \\
\hline MC4 & $1.95 \pm 0.35$ & $1 \mathrm{y} 3 \mathrm{~m}$ & $2 \mathrm{y} 3 \mathrm{~m}$ & $2 \mathrm{y} 3 \mathrm{~m}$ & $1 \mathrm{y} 3 \mathrm{~m}-2 \mathrm{y} 3 \mathrm{~m}$ \\
\hline MC5 & $1.99 \pm 0.34$ & $1 \mathrm{y} 3 \mathrm{~m}$ & $2 \mathrm{y} 3 \mathrm{~m}$ & $2 \mathrm{y} 3 \mathrm{~m}$ & $1 \mathrm{y} 3 \mathrm{~m}-2 \mathrm{y} 3 \mathrm{~m}$ \\
\hline PP1 & $2.93 \pm 0.43$ & $2 \mathrm{y} 3 \mathrm{~m}$ & $3 y 3 m$ & $3 y 3 \mathrm{~m}$ & $2 y 3 m-3 y 3 m$ \\
\hline PP2 & $2.29 \pm 0.79$ & $1 \mathrm{y} 3 \mathrm{~m}$ & $1 \mathrm{y} 9 \mathrm{~m}$ & $3 y 3 m$ & $1 \mathrm{y} 3 \mathrm{~m}-3 \mathrm{y} 3 \mathrm{~m}$ \\
\hline PP3 & $1.85 \pm 0.44$ & $10 \mathrm{~m}$ & $1 \mathrm{y} 9 \mathrm{~m}$ & $2 \mathrm{y} 3 \mathrm{~m}$ & $10 \mathrm{~m}-2 \mathrm{y} 3 \mathrm{~m}$ \\
\hline PP4 & $1.86 \pm 0.43$ & $10 \mathrm{~m}$ & $1 \mathrm{y} 9 \mathrm{~m}$ & $2 \mathrm{y} 3 \mathrm{~m}$ & $10 \mathrm{~m}-2 \mathrm{y} 3 \mathrm{~m}$ \\
\hline PP5 & $2.79 \pm 0.72$ & $1 \mathrm{y} 9 \mathrm{~m}$ & $2 \mathrm{y} 9 \mathrm{~m}$ & $3 y 9 m$ & $1 y 9 m-3 y 9 m$ \\
\hline
\end{tabular}

Table-2: Descriptive statistics for various parameters for boys.

\begin{tabular}{|c|c|c|c|c|c|}
\hline \multicolumn{6}{|c|}{ PERCENTILE } \\
\hline PARAMETER & MEAN \pm SD & $5^{\text {th }}$ & $50^{\text {th }}$ & $95^{\text {th }}$ & RANGE \\
\hline DP1 & $1.87 \pm 0.38$ & $10 \mathrm{~m}$ & $1 \mathrm{y} 9 \mathrm{~m}$ & $2 \mathrm{y} 3 \mathrm{~m}$ & $10 \mathrm{~m}-2 \mathrm{y} 3 \mathrm{~m}$ \\
\hline DP2 & $3.22 \pm 0.61$ & $1 \mathrm{y} 9 \mathrm{~m}$ & $3 y 3 \mathrm{~m}$ & $3 y 9 m$ & $1 \mathrm{y} 9 \mathrm{~m}-3 \mathrm{y} 9 \mathrm{~m}$ \\
\hline DP3 & $1.65 \pm 0.20$ & $1 \mathrm{y} 3 \mathrm{~m}$ & $1 \mathrm{y} 9 \mathrm{~m}$ & $1 \mathrm{y} 9 \mathrm{~m}$ & $1 \mathrm{y} 3 \mathrm{~m}-1 \mathrm{y} 9 \mathrm{~m}$ \\
\hline DP4 & $1.66 \pm 0.20$ & $1 \mathrm{y} 3 \mathrm{~m}$ & $1 \mathrm{y} 9 \mathrm{~m}$ & $1 \mathrm{y} 9 \mathrm{~m}$ & $1 \mathrm{y} 3 \mathrm{~m}-1 \mathrm{y} 9 \mathrm{~m}$ \\
\hline DP5 & $3.25 \pm 0.63$ & $1 \mathrm{y} 9 \mathrm{~m}$ & $3 y 3 \mathrm{~m}$ & $3 \mathrm{y} 9 \mathrm{~m}$ & $1 \mathrm{y} 9 \mathrm{~m}-3 \mathrm{y} 9 \mathrm{~m}$ \\
\hline MP2 & $2.24 \pm 0.45$ & $1 \mathrm{y} 9 \mathrm{~m}$ & $2 \mathrm{y} 3 \mathrm{~m}$ & $2 \mathrm{y} 9 \mathrm{~m}$ & $1 \mathrm{y} 9 \mathrm{~m}-2 \mathrm{y} 9 \mathrm{~m}$ \\
\hline MP3 & $1.94 \pm 0.27$ & $1 \mathrm{y} 9 \mathrm{~m}$ & $1 \mathrm{y} 9 \mathrm{~m}$ & $2 \mathrm{y} 3 \mathrm{~m}$ & $1 y 9 m-2 y 3 m$ \\
\hline MP4 & $1.95 \pm 0.28$ & $1 \mathrm{y} 9 \mathrm{~m}$ & $1 \mathrm{y} 9 \mathrm{~m}$ & $2 \mathrm{y} 3 \mathrm{~m}$ & $1 \mathrm{y} 9 \mathrm{~m}-2 \mathrm{y} 3 \mathrm{~m}$ \\
\hline MP5 & $1.82 \pm 0.23$ & $1 \mathrm{y} 4 \mathrm{~m}$ & $1 \mathrm{y} 9 \mathrm{~m}$ & $2 \mathrm{y} 3 \mathrm{~m}$ & $1 \mathrm{y} 4 \mathrm{~m}-2 \mathrm{y} 3 \mathrm{~m}$ \\
\hline Med epi & $8.37 \pm 1.06$ & 6y6m & $8 y 6 m$ & $9 y 6 m$ & $6 y 6 m-9 y 6 m$ \\
\hline Pis & $11.12 \pm 0.70$ & $9 y 6 m$ & $11 \mathrm{y} 6 \mathrm{~m}$ & $11 \mathrm{y} 6 \mathrm{~m}$ & $9 y 6 m-11 y 6 m$ \\
\hline Olec & $10.96 \pm 0.87$ & $8 \mathrm{y} 6 \mathrm{~m}$ & $11 \mathrm{y} 6 \mathrm{~m}$ & $11 \mathrm{y} 6 \mathrm{~m}$ & $8 y 6 m-11 y 6 m$ \\
\hline Ul sty & $9.98 \pm 0.96$ & $7 \mathrm{y} 6 \mathrm{~m}$ & $10 \mathrm{y} 6 \mathrm{~m}$ & $10 \mathrm{y} 6 \mathrm{~m}$ & $7 y 6 m-10 y 6 m$ \\
\hline$\overline{\mathrm{DU}}$ & $8.32 \pm 1.21$ & $6 y 6 \mathrm{~m}$ & $8 y 6 m$ & $9 y 6 \mathrm{~m}$ & $6 y 6 m-9 y 6 m$ \\
\hline Lat-epi & $10.90 \pm 0.84$ & $9 y 6 m$ & $11 \mathrm{y} 6 \mathrm{~m}$ & $11 \mathrm{y} 6 \mathrm{~m}$ & $9 y 6 m-11 y 6 m$ \\
\hline Troch & $10.94 \pm 0.81$ & $9 y 6 m$ & $11 \mathrm{y} 6 \mathrm{~m}$ & $11 \mathrm{y} 6 \mathrm{~m}$ & $9 y 6 m-11 y 6 m$ \\
\hline Rad-hea & $7.09 \pm 0.49$ & $6 y 6 \mathrm{~m}$ & $7 y 6 m$ & $7 y 6 m$ & 6y6m-7y6m \\
\hline Pat & $4.86 \pm 0.52$ & $4 y s 3 m$ & $4 \mathrm{y} 9 \mathrm{~m}$ & $5 y 6 m$ & $4 y 3 m-5 y 6 m$ \\
\hline
\end{tabular}

The mean age of appearance of distal radius was 1year 6months \pm 3 months. The distal ulna had a wide range of appearance (6.6- 9.6 for boys \& 5.6-9.6 for girls.) The Ulnar styloid also had a wide range of appearance. The olecranon 
showed a mean of $10.9 \pm 0.8$ in boys and $10.3 \pm 1$ in girls. The 50th and 95th percentile of the radial head was $6 y 6 \mathrm{~m}$ and $7 \mathrm{y} 6 \mathrm{~m}$ in girls respectively and in boys both 50 th and 95 th percentile was $7 \mathrm{y} 6 \mathrm{~m}$. The $50^{\text {th }} \& 95$ th percentile for boys $\&$ girls for medial epicondyle was $8 \mathrm{y} 6 \mathrm{~m}$ and $9 \mathrm{y} 6 \mathrm{~m}$ respectively. DP- distal phalanx We found that the mean age of appearance of patellar ossification was similar in both boys and girls (mean age 4.8 0.5 ).

$\begin{array}{lll}\text { PP } & - & \text { proximal phalanx } \\ \text { MP } & - & \text { middle phalanx } \\ \text { DP } & - & \text { distal phalanx } \\ \text { Med epi } & - & \text { medial epicondyle } \\ \text { Pis } & - & \text { pisiform } \\ \text { Olec } & - & \text { olecranon } \\ \text { Ul sty } & - & \text { ulnar styloid } \\ \text { DU } & - & \text { distal ulna } \\ \text { Lat epi } & - & \text { lateral epicondyle } \\ \text { Troch } & - & \text { trochlea } \\ \text { Rad head- } & \text { radial head } \\ \text { Pat } & - & \text { patella } \\ \text { DR } & - & \text { distal radius } \\ \text { C1 } & - & \text { capitate } \\ \text { C2 } & - & \text { hamate } \\ \text { C3 } & - & \text { triquetrum } \\ \text { C4 } & - & \text { lunate } \\ \text { C5 } & - & \text { scaphoid } \\ \text { C6 } & - & \text { trapezium } \\ \text { C7 } & - & \text { trapezoid } \\ \text { MC } & - & \text { metacarpal } \\ & & \end{array}$

Table-3: Descriptive statistics for various parameters for girls.

\begin{tabular}{|c|c|c|c|c|c|}
\hline \multicolumn{7}{|c|}{ PERCENTILE } \\
\hline PARAMETER & MEAN + SD & $\mathbf{5}^{\text {th }}$ & $\mathbf{5 0}^{\text {th }}$ & $\mathbf{9 5}^{\text {th }}$ & RANGE \\
\hline C1 & $0.25 \pm 0.00$ & $3 \mathrm{~m}$ & $3 \mathrm{~m}$ & $3 \mathrm{~m}$ & $3 \mathrm{~m}-3 \mathrm{~m}$ \\
\hline C2 & $1.66 \pm 1.92$ & $3 \mathrm{~m}$ & $3 \mathrm{~m}$ & $6 \mathrm{~m}$ & $3 \mathrm{~m}-6 \mathrm{~m}$ \\
\hline C3 & $4.03 \pm 1.19$ & $2 \mathrm{y} 9 \mathrm{~m}$ & $3 \mathrm{y} 3 \mathrm{~m}$ & $6 \mathrm{y} 4 \mathrm{~m}$ & $2 \mathrm{y} 9 \mathrm{~m}-6 \mathrm{y} 4 \mathrm{~m}$ \\
\hline C4 & $5.07 \pm 1.45$ & $3 \mathrm{y} 3 \mathrm{~m}$ & $4 \mathrm{y} 9 \mathrm{~m}$ & $6 \mathrm{y} 6 \mathrm{~m}$ & $3 \mathrm{y} 3 \mathrm{~m}-6 \mathrm{y} 6 \mathrm{~m}$ \\
\hline C5 & $7.13 \pm 1.98$ & $4 \mathrm{y} 3 \mathrm{~m}$ & $7 \mathrm{y} 6 \mathrm{~m}$ & $9 \mathrm{y} 6 \mathrm{~m}$ & $4 \mathrm{y} 3 \mathrm{~m}-9 \mathrm{y} 6 \mathrm{~m}$ \\
\hline C6 & $6.18 \pm 1.60$ & $4 \mathrm{y} 3 \mathrm{~m}$ & $5 \mathrm{y} 6 \mathrm{~m}$ & $9 \mathrm{y} 8 \mathrm{~m}$ & $4 \mathrm{y} 3 \mathrm{~m}-9 \mathrm{y} 8 \mathrm{~m}$ \\
\hline C7 & $7.87 \pm 1.10$ & $5 \mathrm{y} 6 \mathrm{~m}$ & $7 \mathrm{y} 6 \mathrm{~m}$ & $9 \mathrm{y} 8 \mathrm{~m}$ & $5 \mathrm{y} 6 \mathrm{~m}-9 \mathrm{y} 8 \mathrm{~m}$ \\
\hline DR & $1.52 \pm 0.28$ & $1 \mathrm{y} 3 \mathrm{~m}$ & $1 \mathrm{y} 9 \mathrm{~m}$ & $1 \mathrm{y} 9 \mathrm{~m}$ & $1 \mathrm{y} 3 \mathrm{~m}-1 \mathrm{y} 9 \mathrm{~m}$ \\
\hline MC1 & $3.23 \pm 0.52$ & $2 \mathrm{y} 3 \mathrm{~m}$ & $2 \mathrm{y} 6 \mathrm{~m}$ & $3 \mathrm{y} 6 \mathrm{~m}$ & $2 \mathrm{y} 3 \mathrm{~m}-3 \mathrm{y} 6 \mathrm{~m}$ \\
\hline MC2 & $1.86 \pm 0.40$ & $1 \mathrm{y} 3 \mathrm{~m}$ & $1 \mathrm{y} 9 \mathrm{~m}$ & $2 \mathrm{y} 3 \mathrm{~m}$ & $1 \mathrm{y} 3 \mathrm{~m}-2 \mathrm{y} 3 \mathrm{~m}$ \\
\hline MC3 & $1.85 \pm 0.39$ & $1 \mathrm{y} 3 \mathrm{~m}$ & $2 \mathrm{y} 3 \mathrm{~m}$ & $2 \mathrm{y} 3 \mathrm{~m}$ & $1 \mathrm{y} 3 \mathrm{~m}-2 \mathrm{y} 3 \mathrm{~m}$ \\
\hline MC4 & $1.85 \pm 0.40$ & $1 \mathrm{y} 3 \mathrm{~m}$ & $2 \mathrm{y} 3 \mathrm{~m}$ & $2 \mathrm{y} 3 \mathrm{~m}$ & $1 \mathrm{y} 3 \mathrm{~m}-2 \mathrm{y} 3 \mathrm{~m}$ \\
\hline MC5 & $1.93 \pm 0.40$ & $1 \mathrm{y} 3 \mathrm{~m}$ & $2 \mathrm{y} 3 \mathrm{~m}$ & $2 \mathrm{y} 3 \mathrm{~m}$ & $1 \mathrm{y} 3 \mathrm{~m}-2 \mathrm{y} 3 \mathrm{~m}$ \\
\hline PP1 & $2.72 \pm 0.47$ & $2 \mathrm{y} 3 \mathrm{~m}$ & $2 \mathrm{y} 9 \mathrm{~m}$ & $3 \mathrm{y} 3 \mathrm{~m}$ & $2 \mathrm{y} 3 \mathrm{~m}-3 \mathrm{y} 3 \mathrm{~m}$ \\
\hline PP2 & $1.97 \pm 0.77$ & $10 \mathrm{~m}$ & $1 \mathrm{y} 9 \mathrm{~m}$ & $3 \mathrm{y} 3 \mathrm{~m}$ & $10 \mathrm{~m}-3 \mathrm{y} 3 \mathrm{~m}$ \\
\hline PP3 & $1.65 \pm 0.48$ & $10 \mathrm{~m}$ & $1 \mathrm{y} 9 \mathrm{~m}$ & $2 \mathrm{y} 3 \mathrm{~m}$ & $10 \mathrm{~m}-2 \mathrm{y} 3 \mathrm{~m}$ \\
\hline PP4 & $1.67 \pm 0.49$ & $10 \mathrm{~m}$ & $1 \mathrm{y} 9 \mathrm{~m}$ & $2 \mathrm{y} 3 \mathrm{~m}$ & $10 \mathrm{~m}-2 \mathrm{y} 3 \mathrm{~m}$ \\
\hline PP5 & $2.12 \pm 0.53$ & $1 \mathrm{y} 3 \mathrm{~m}$ & $2 \mathrm{y} 3 \mathrm{~m}$ & $2 \mathrm{y} 9 \mathrm{~m}$ & $1 \mathrm{y} 3 \mathrm{~m}-2 \mathrm{y} 9 \mathrm{~m}$ \\
\hline
\end{tabular}


Table-4: Descriptive statistics for various parameters for girls.

\begin{tabular}{|c|c|c|c|c|c|}
\hline \multicolumn{6}{|c|}{ PERCENTILE } \\
\hline PARAMETER & MEAN \pm SD & $5^{\text {th }}$ & $50^{\text {th }}$ & $95^{\text {th }}$ & RANGE \\
\hline DP1 & $1.88 \pm 0.49$ & $10 \mathrm{~m}$ & $2 \mathrm{y} 3 \mathrm{~m}$ & $2 \mathrm{y} 3 \mathrm{~m}$ & $10 \mathrm{~m}-2 \mathrm{y} 3 \mathrm{~m}$ \\
\hline DP2 & $2.94 \pm 0.90$ & $1 \mathrm{y} 3 \mathrm{~m}$ & $3 y 3 \mathrm{~m}$ & $3 \mathrm{y} 9 \mathrm{~m}$ & $1 \mathrm{y} 3 \mathrm{~m}-3 \mathrm{y} 9 \mathrm{~m}$ \\
\hline DP3 & $1.43 \pm 0.24$ & $1 \mathrm{y} 3 \mathrm{~m}$ & $1 \mathrm{y} 3 \mathrm{~m}$ & $1 \mathrm{y} 9 \mathrm{~m}$ & $1 \mathrm{y} 3 \mathrm{~m}-1 \mathrm{y} 9 \mathrm{~m}$ \\
\hline DP4 & $1.43 \pm 0.24$ & $1 \mathrm{y} 3 \mathrm{~m}$ & $1 \mathrm{y} 3 \mathrm{~m}$ & $1 \mathrm{y} 9 \mathrm{~m}$ & $1 y 3 m-1 y 9 m$ \\
\hline DP5 & $3.12 \pm 0.75$ & $1 \mathrm{y} 3 \mathrm{~m}$ & $3 y 3 \mathrm{~m}$ & $3 \mathrm{y} 9 \mathrm{~m}$ & $1 y 3 m-3 y 9 m$ \\
\hline MP2 & $2.10 \pm 0.50$ & $1 \mathrm{y} 3 \mathrm{~m}$ & $2 \mathrm{y} 3 \mathrm{~m}$ & $2 \mathrm{y} 9 \mathrm{~m}$ & $1 \mathrm{y} 3 \mathrm{~m}-2 \mathrm{y} 9 \mathrm{~m}$ \\
\hline MP3 & $1.85 \pm 0.38$ & $1 \mathrm{y} 3 \mathrm{~m}$ & $1 \mathrm{y} 9 \mathrm{~m}$ & $2 \mathrm{y} 3 \mathrm{~m}$ & $1 \mathrm{y} 3 \mathrm{~m}-2 \mathrm{y} 3 \mathrm{~m}$ \\
\hline MP4 & $1.84 \pm 0.39$ & $1 \mathrm{y} 3 \mathrm{~m}$ & $1 \mathrm{y} 9 \mathrm{~m}$ & $2 \mathrm{y} 3 \mathrm{~m}$ & $1 \mathrm{y} 3 \mathrm{~m}-2 \mathrm{y} 3 \mathrm{~m}$ \\
\hline MP5 & $1.88 \pm 0.37$ & $1 \mathrm{y} 3 \mathrm{~m}$ & $1 \mathrm{y} 9 \mathrm{~m}$ & $2 \mathrm{y} 3 \mathrm{~m}$ & $1 \mathrm{y} 3 \mathrm{~m}-2 \mathrm{y} 3 \mathrm{~m}$ \\
\hline Med epi & $8.16 \pm 1.08$ & 6y6m & $8 \mathrm{y} 6 \mathrm{~m}$ & $9 y 6 m$ & $6 y 6 m-9 y 6 m$ \\
\hline Pis & $10.54 \pm 0.95$ & $8 \mathrm{y} 6 \mathrm{~m}$ & $10 \mathrm{y} 6 \mathrm{~m}$ & $11 \mathrm{y} 6 \mathrm{~m}$ & $8 y 6 m-11 y 6 m$ \\
\hline Olec & $10.39 \pm 1.08$ & $8 y 6 m$ & $10 \mathrm{y} 6 \mathrm{~m}$ & $11 \mathrm{y} 6 \mathrm{~m}$ & $8 y 6 m-11 y 6 m$ \\
\hline Ul sty & $9.40 \pm 1.08$ & $7 y 6 m$ & $9 y 6 m$ & $10 y 6 m$ & $7 y 6 m-10 y 6 m$ \\
\hline DU & $8.15 \pm 1.27$ & $5 \mathrm{y} 6 \mathrm{~m}$ & $8 \mathrm{y} 6 \mathrm{~m}$ & $9 y 6 m$ & $5 y 6 m-9 y 6 m$ \\
\hline Lat-epi & $10.75 \pm 0.89$ & $9 y 6 m$ & $11 \mathrm{y} 6 \mathrm{~m}$ & $11 \mathrm{y} 6 \mathrm{~m}$ & 9y6m-11y6m \\
\hline Troch & $10.95 \pm 0.84$ & $9 y 6 m$ & $11 \mathrm{y} 6 \mathrm{~m}$ & $11 \mathrm{y} 6 \mathrm{~m}$ & $9 y 6 m-11 y 6 m$ \\
\hline Rad-hea & $7.00 \pm 0.50$ & 6y6m & 6y6m & $7 y 6 m$ & $6 y 6 m-7 y 6 m$ \\
\hline Pat & $4.85 \pm 0.52$ & $4 y 3 m$ & $4 y 9 m$ & $5 y 6 m$ & $4 y 3 m-5 y 6 m$ \\
\hline
\end{tabular}

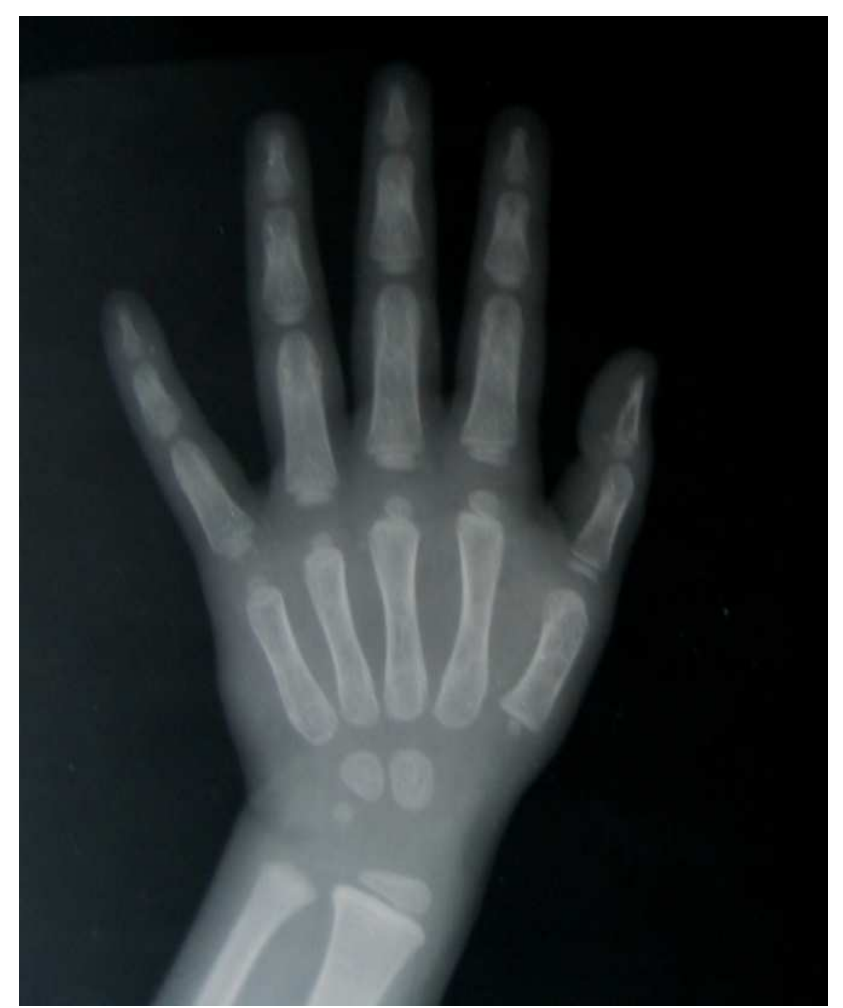

Fig-1: The first metacarpal is seen in this 3 year old

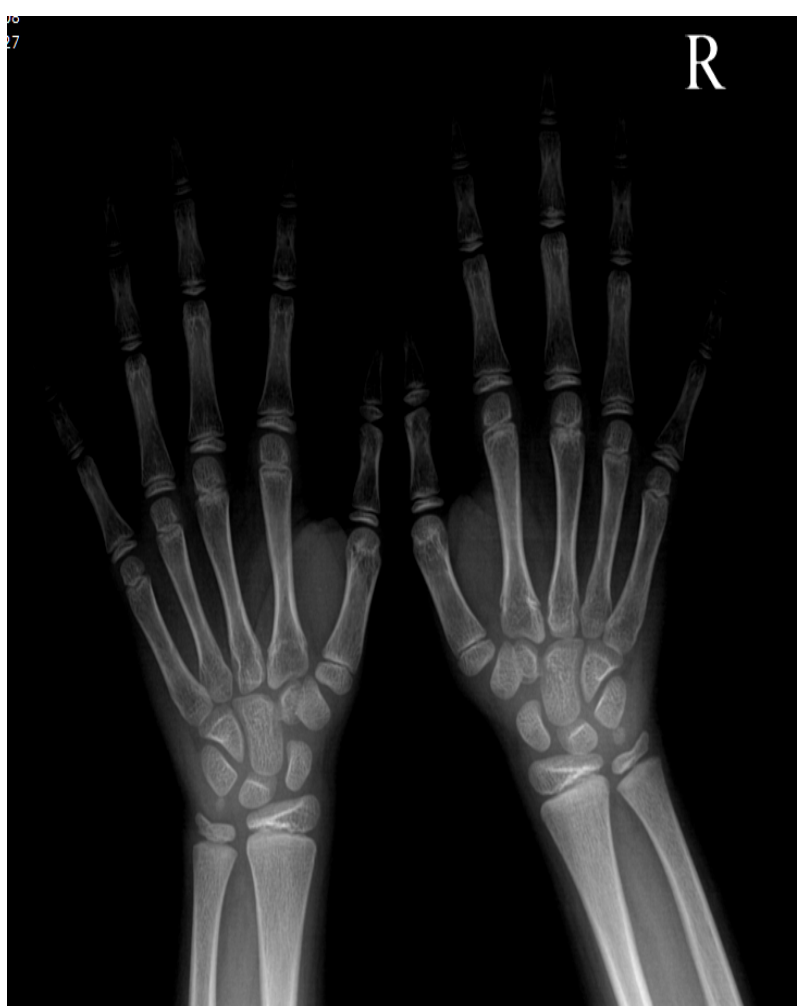

Fig-2: The pisiform is seen in this 10 year old girl 


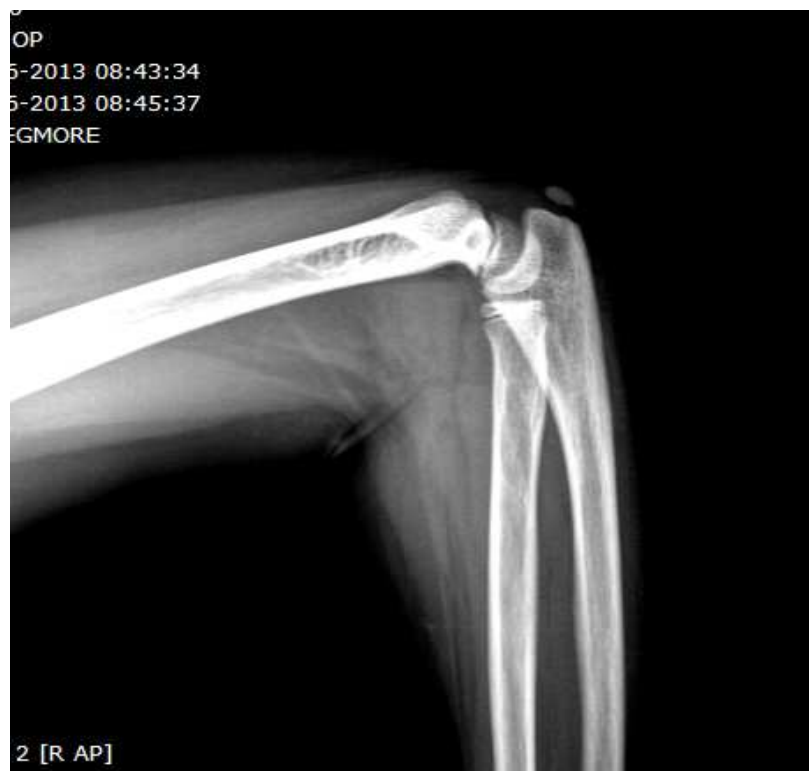

Fig-3: Olecranon centre in a 11year old girl

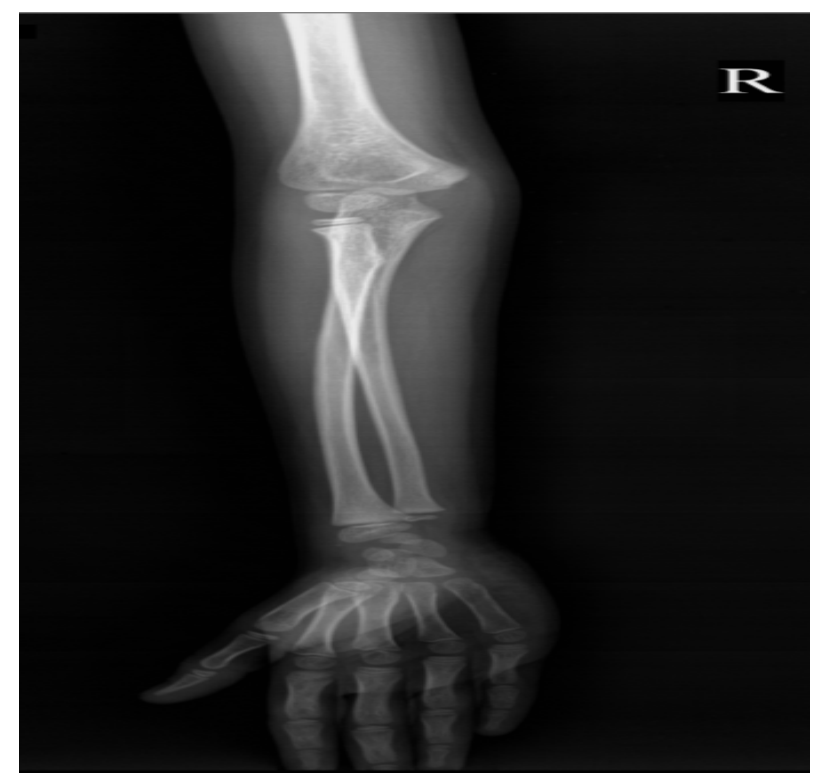

Fig-4: The radial head and medial epicondyle is seen in this 7 year old boy

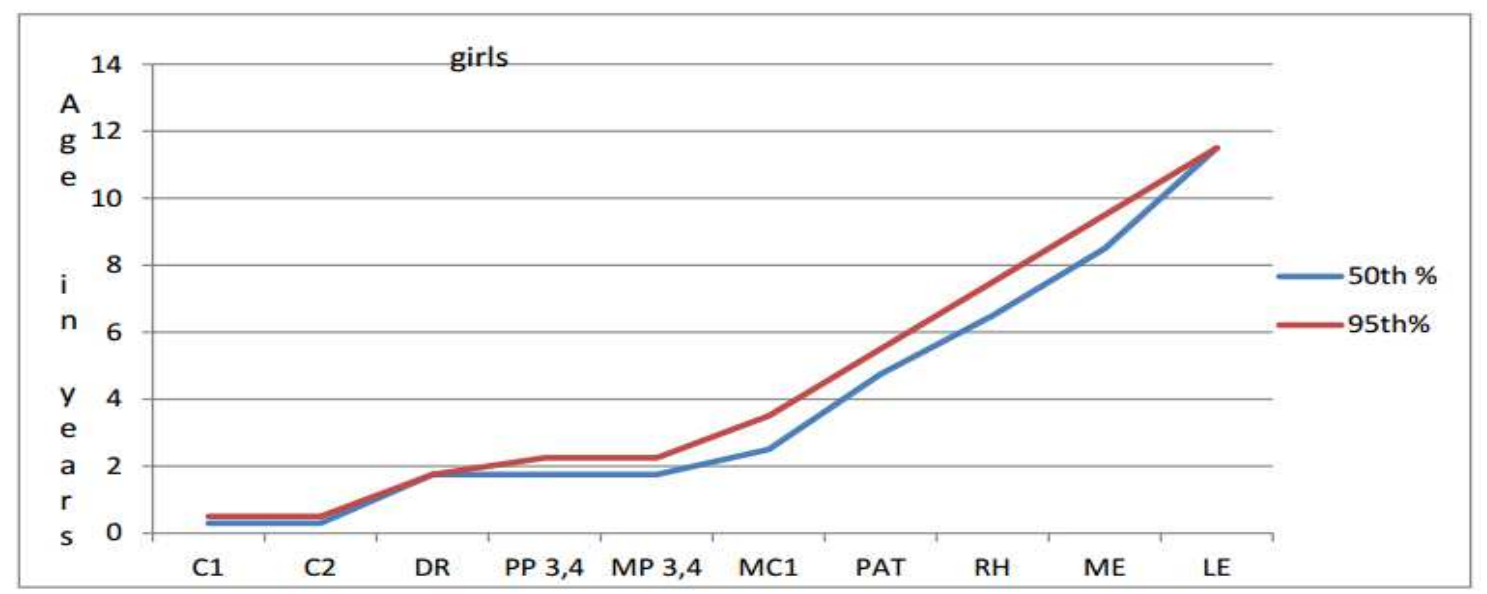

Fig 5- $50^{\text {th }}$ and $95^{\text {th }}$ percentile of ossification centres in girls

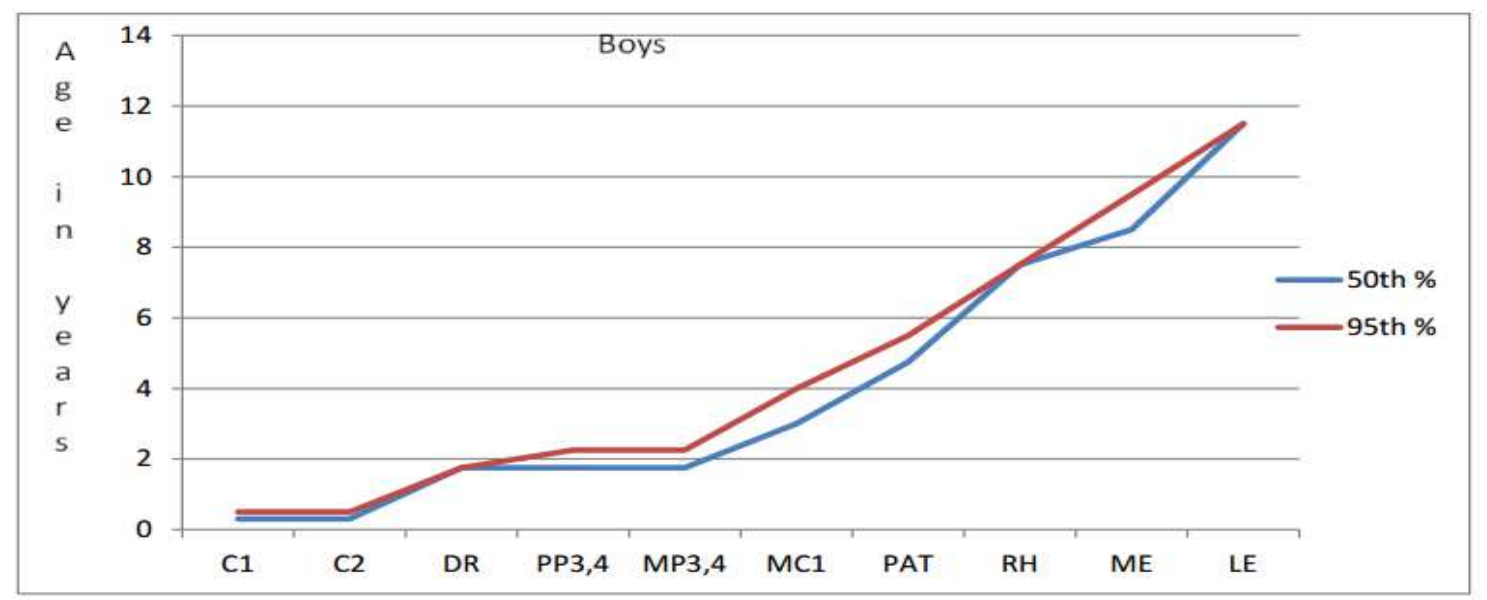

Fig 6- $50^{\text {th }}$ and $95^{\text {th }}$ percentile of ossification centres in boys 


\section{Discussion}

The $\mathrm{x}$-rays of the hands has traditionally been used to study bone age. The large number of centers in the hand and the different times of their appearance were baffling to many which lead to an arbitrary notion of deducing age based on just the number of carpal bones seen [5]. The elbow also has a number of epiphyses that are readily seen in the antero-posterior and lateral (for olecranon centre) views. Thus, these two regions enable the study of many centres. The patella is not generally noted in textbooks of forensic medicine but many workers have studied its appearance. It is seen to show great constancy and that is why this was also included in our study.

Carpal bones: A widely held presumption that the age of the child is equal to the number of carpal bones plus two is baseless as seen in the study. The capitate and hamate are present at birth, the 95th percentile level being reached at $3 \mathrm{~m}$ in girls and $6 \mathrm{~m}$ in boys. The next appearing triquetrum may be present by $2 \mathrm{y} 9 \mathrm{~m}$ but can be as late as $7 \mathrm{y} 6 \mathrm{~m}$ in boys and $6 \mathrm{y} 4 \mathrm{~m}$ in girls. The lunate can be delayed as long as $6 \mathrm{y} 6 \mathrm{~m}$ in girls and $9 \mathrm{y}$ $6 \mathrm{~m}$ in boys. The same variability can be said of other carpal bones, except the pisiform. Maniar [9] also found a wide spectrum in the appearance of carpal bones. This is sufficient evidence to discard the old formula of the number of carpals and age.

Pisiform- The pisiform center was reported by Bajaj et al [10] at 13 years for boys and $10 \mathrm{y} 3 \mathrm{~m}$ for girls. The western standards [11] give a mean of $9 \mathrm{y} 9 \mathrm{~m}$ for boys and $8 \mathrm{y}$ for girls. Our 50th percentile was $10 \mathrm{y} 6 \mathrm{~m}$ for girls and $11 \mathrm{y} 6 \mathrm{~m}$ for boys, a reading approaching western levels. In the Greulich and Pyle atlas [1] the pisiform is seen at $9 \mathrm{y} 6 \mathrm{~m}$ years in girls and 10 in boys.

When we consider this with our 5 th percentile values the global secular trend in growth and development is seen in the advance by 6 months in our boys. There is an additional advance of one year in our girls probably due to the added factor of early pubertal growth spurt.

Olecranon- Our 50th percentile values were 10.3 for girls and 10.9 for boys. The fifth percentile was 8.6 for boys and girls. In practice it can be timed at 8 to $10 \mathrm{y}$.

Capitulum- The capitulum was present in all the films at the time elbow $x$-rays were included in the age groups. The timing of appearance is around a year.
Patella- Garn's [11] 7.6-6 years in boys, and 2 to 4 in girls are very different from ours. Our values range from $4 \mathrm{y} 6 \mathrm{~m}$ to $5 \mathrm{y} 6 \mathrm{~m}$ in both boys and girls. The patella is not taken into account by Greulich and Pyle [1] whose study is only of the hands. Bajaj et [10] al do not mention the patella.

Acheson [12] applied the Oxford maturity units to the patella. But the frequency distribution was very irregular and was not followed. We propose that the patella would be a helpful indicator for age estimation since it falls between the time of appearance of hand centers (excluding carpals) and that of elbow centers. If patella is seen the child has crossed four years. In the study by Garn [11] the difference between boys and girls was very wide. The range for boys was 5 to 6 and girls $2 \mathrm{y} 6 \mathrm{~m}$ to $4 \mathrm{y}$. But this wide difference was not seen in our children and none of our girls had the patella at Garn's [11] value of 2.6 years. Therefore, there is a great constancy in the appearance of the patella by around $4 \mathrm{y}$. Variability is minimal.

There is no difference between boys and girls and the patella serves to bridge the gap between timing of hand and elbow centers.

Distal Radius- Bajaj and Bharadwaj [10] showed a wide range of 1.7 to 3.5 in girls. According to western standards [11] the distal radius can show up as early as 9 to 10 months. In our study the 50th percentile and the 5 th percentile was at $1 \mathrm{y} 9 \mathrm{~m}$, the same for both sexes. By two years, it was definitely present. In practice it can be timed at one and half to two years.

Distal Ulna and Ulnar styloid- Bajaj and Bharadwaj's [10], Garn's [11] study and ours showed wide range. These may be eliminated in routine practice.

Elbow- Another eponym for age evaluation on the basis of centres in the elbow is CRITOE [5] designating the order of appearance as capitulum, radial head, internal epicondyle, trochlea, olecranon and external epicondyle. According to this, the capitulum ossifies by age 1 and two years is added for the appearance of each successive ossification center. This scheme is far from accurate as you will see below.

Trochlea- The trochlea appears at 9-11 years in agreement with forensic medicine textbooks, [13, 14]. 
Medial epicondyle- The 50th percentile for us was at $8 \mathrm{y} 6 \mathrm{~m}$ corresponding to the value of 7 to 8 years in V.V. Pillay's textbook of forensic medicine [13]. In Narayana Reddy's Forensic Medicine [14], the value is different at 6-7y. This shows the lack of uniformity in values even in Indian books. Western levels [11] are too early, earliest of $3 y 6 \mathrm{~m}$ in girls. None of our children had the medial epicondyle at $3-4 y$. In routine practice the medial epicondyle can be timed at 8 years.

Radial head- The 50th percentile in our study was 7.5 for boys and 6.6 for girls and this does not match with forensic textbooks at 5 years. Bharadwaj [10] reports means of $6 \mathrm{y} 2 \mathrm{~m}$ for boys and $3 \mathrm{y} 6 \mathrm{~m}$ for girls. No child in our study had radial head at 5y. Garn's 50th percentile values were also too early at $4 \mathrm{y}$ for boys and $3 y$ for girls. We time the radial head at 6 to $7 y$ and is quite a constant in day to day practice.

Lateral epicondyle-In 1970[10], its appearance was 9 to 14 in boys and 7-12 in girls 5. By 1980, the lateral epicondyle was seen at 13-14y (unpublished dataElizabeth John). In our study it was seen by $11 \mathrm{y} 6 \mathrm{~m}$. The center can appear as early as 9 years in both sexes, but it is definitely seen by $11 \mathrm{y} 6 \mathrm{~m}$.

This is very clear evidence for the general improvement in the socio-economic status and nutrition that has led to quicker skeletal maturation so that we now equal the western standards of Garn. The advancement in puberty due to better nutrition is also another cause for the quicker skeletal maturation.

Hands- Forensic medicine textbooks $[13,14]$ put down the age of appearance of phalangeal centers as two to four years. While the third and fourth proximal phalanges can appear as early as $10 \mathrm{~m}$, the 50th percentile is at one year $9 \mathrm{~m}$. All the centres of the third and fourth fingers are present by two years three months. The tables show we are close to values seen in the Greulich and Pyle atlas.

The first metacarpal follows a different timetable. In Greulich and Pyle's atlas, the first metacarpal centre is seen at $2 \mathrm{y} 8 \mathrm{~m}$ in boys and $2 \mathrm{y}$ in girls. Bajaj's Delhi population [10] showed a great difference- $4 \mathrm{y} 2 \mathrm{~m}$ in boys and $2 \mathrm{y} 1 \mathrm{~m}$ in girls. Forensic medicine textbooks club the first metacarpal with the other metacarpals. But the first metacarpal can be used as a marker for $2 \mathrm{y} 6 \mathrm{~m}$ to $3 \mathrm{y}$. The centre can appear as early as $2 \mathrm{y}$ in girls and $2 \mathrm{y} 9 \mathrm{~m}$ in boys.

\section{Conclusion}

There may be many a debate between the Greulich and Pyle atlas method and the more accurate TW2 method. But, the age old method of telling age based on only the time of appearance of epiphyseal centers is still being used. Re- examination of the technique has revealed a positive secular trend in growth of our children. We consider only a few of these centres to come to a conclusion of whether the child is progressing normally towards maturity or not. The atlas method and the TW2 method requires proper positioning of the hands, time to interpret and trained manpower to help in the interpretation- all of which are practically not often possible.

There is also software for automated measurement of bone age on the net (boneXpert- wwwbonexpert.com) that can assess age on online submission of an x-ray of the hands. This requires a payment in pounds. Our method is a quick method, requires no training and is easily incorporated into the routine OP situation. For those of us who are concerned with initial diagnoses and quick separation of those with growth disorders, this method continues to be a useful tool.

Further accurate assessment can be done by the TW2 method which might be necessary if endocrine treatment is started or if final height is to be predicted in case of planning certain orthopedic procedures.

Funding: Nil, Conflict of interest: None initiated, Permission from IRB: Yes

\section{References}

1. Greulich WW, Pyle SI. Radiographic Atlas of skeletal development of hand and wrist. Stanford: Stanford University Press 1950 (reprint 1954).

2. Tanner JM, Whitehouse RH, Marshall WA, Goldstein H. Assessment of skeletal maturityand prediction of adult height. London: Academic Press, 1975.

3. Bull RK, Edwards PD, Kemp PM, Fry S, Hughes IA. Bone age assessment: a large scale comparison of the Greulich and Pyle, and Tanner and Whitehouse (TW2) methods. Arch Dis Child. 1999 Aug;81(2):172-3.

4. Buckler JM. How to make the most of bone ages. Arch Dis Child. 1983 Oct;58(10):761-3. 
5. Goyal A, Gaillard F. Elbow ossification. Available at https://radiopaedia.org/articles/ elbow-ossification.

6. Satoh M. Bone age: assessment methods and clinical applications. Clin Pediatr Endocrinol. 2015 Oct;24(4): 143-52. doi: 10.1297/cpe.24.143. Epub 2015 Oct 24.

7. Khadilkar V, Khadilkar A. Growth charts: A diagnostic tool. Indian J Endocrinol Metab. 2011 Sep; 15 Suppl 3:S166-71. doi: 10.4103/2230-8210.84854.

8. Flor-Cisneros A, Leschek EW, Merke DP, et al: In boys with abnormal developmental tempo, maturation of the skeleton and the hypothalamic- pituitary gonadal axis remains synchronous. J Clin Endocrinol Metab 2004; 89 (1): 236 - 41.

9. Maniar B. Skeletal maturity in Indian children. Indian J Pediatr. 1987 May-Jun;54(3):295-302.
10. Bajaj ID, Bhardwaj OP, Bhardwaj S. Appearance and fusion of important ossification centres: a study in Delhi population. Indian J Med Res. 1967 Oct; 55 (10):1064-7.

11. Garn SM et al Med Radiogr Photogr in Caffey's Pediatric Radiology XIth edition 2008.

12. Acheson RM, Kemp JH, Parfit J. Height, weight, and skeletal maturity in the first five years of life. Lancet. 1955 Apr 2;268(6866):691-2.

13. VV Pillay, Chap 4 in Textbook of Forensic Medicine and Toxicology; 14th Edition Paras Publishers Hyderabad 2004.

14. Dr. KS Narayana Reddy, Chapter 4 in The Essentials of Forensic Medicine and Toxicology 24th Edition Published by Suguna Devi Hyderabad 2005.

\section{How to cite this article?}

Vijayalaksmi G, Rajiah J. Skeletal Maturation in the pediatric population in a large tertiary care hospital in South India. Int J Med Res Rev 2016;4(10):1838-1846.doi:10.17511/ijmrr. 2016.i10.21. 